\title{
ENTREPRENEURS' ACCEPTENCE ABILITY IN LEARNING THE USE OF DIGITAL MEDIA
}

\author{
Miftahul Rozaq*1, Sri Hastjarjo*), Yulius Slamet $\left.{ }^{*}\right)$ \\ ${ }^{*}$ Magister Program of Communication Science, Faculty of Social and Political Sciences, Universitas Sebelas Maret \\ Jl. Ir. Sutami 36A Surakarta, Central Java, 57126 Indonesia
}

\begin{abstract}
In today's digital era, learning the use of digital media for entrepreneurs is mostly done by imitation through various role models on digital media such as content creators who display various content strategies for business development. However, success in learning through observation on digital media depends on the entrepreneurial receptivity ability to assess, interpret and apply the knowledge gained from the observed results. This study aims to investigate the acceptance of entrepreneurs in learning the use of digital media in an effort to develop their business. The research was conducted with a qualitative approach using a case study method on six novice entrepreneurs from micro, small and medium enterprises in Surakarta City, Indonesia. In-depth interviews were conducted from October 2020 - to March 2021. The results showed that three entrepreneurs in each use of digital media strategies were in a dominant acceptance position, two entrepreneurs were in a negotiating position, and one entrepreneur was in an oppositional position. Entrepreneurial receptions in the three acceptance positions show, among other things, in the dominant acceptance the entrepreneur makes a similar imitation, in the negotiated acceptance the entrepreneur carries out development, and in the oppositional acceptance the entrepreneur makes a new version.
\end{abstract}

Keywords: case studies, entrepreneurship learning, reception analysis, SMEs. use of digital media strategies

\begin{abstract}
Abstrak: Di era digital saat ini, dalam mempelajari penggunaan media digital bagi wirausaha banyak dilakukan dengan cara peniruan melalui berbagai panutan pada media digital seperti para konten kreator yang menampilakan berbagai strategi konten untuk pengembangan usaha. Namun, kesuksesan dalam belajar melalui pengamatan pada media digital tergantung pada kemampuan penerimaan wirausaha dalam menilai, menafsirkan dan menerapkan pengetahuan yang diperoleh dari hasil yang diamati. Penelitian ini bertujuan menyelidiki penerimaan wirausaha pemula dalam mempelajari penggunaan media digital dalam upaya mengembangkan usahanya. Penelitian dilakukan dengan pendekatan kualitatif menggunakan metode studi kasus pada enam wirausha pemula dari usaha mikro, kecil dan menengah di Kota Surakarta, Indonesia. Wawancara mendalam dilakukan pada bulan November 2020 - April 2021. Hasil penelitian menunjukkan bahwa tiga wirausaha dalam setiap penggunaan strategi media digital berada pada posisi penerimaan dominan, dua wirausaha berada pada posisi negosiasi, dan satu wirausaha berada pada posisi oposisional. Resepsi wirausaha pada tiga posisi penerimaan menunjukkan, antara lain, dalam penerimaan dominan wirausaha melakukan imitasi serupa, dalam penerimaan yang dinegosiasikan wirausaha melakukan pengembangan, dan dalam penerimaan oposisional wirausaha membuat versi baru.
\end{abstract}

Kata kunci: potensi keuangan UKM, potensi ekonomi daerah, tipologi klassen, location quotient, ekonomi daerah

\footnotetext{
${ }^{1}$ Corresponding author:

Email: miftahulrozaq19@gmail.com
} 


\section{INTRODUCTION}

Building a digital media strategy is important for entrepreneurs who want to start a business and develop a business (Chen et al. 2017; Taiminen and Karjaluoto, 2015), this is to build a business reputation and expand the marketing of the products produced (Horst et al. 2019; Koster and van Stel, 2014; Michaelidou et al. 2011; Stankovska et al. 2016). In contrast to large businesses or established businesses, new businesses do not yet have adequate business credibility, weak business management, and new businesses do not think about the reputation of the business or product at the time it was founded (Bresciani and Eppler, 2010; Rini and Shihab, 2019). The most important thing for new ventures in today's digital era is to build their digital media strategy according to their business goals and specific characteristics (Sardana and Scott-Kemmis, 2010; Sayre et al. 2012).

In today's digital era, entrepreneurs generally use digital media as a marketing communication tool to expand market segmentation of the products they produce. This is in line with the results of research that show various benefits resulting from the use of digital media for new businesses, including as a business communication tool that can simplify various obstacles in the communication process such as accessing customers, suppliers, business partners and various other resources needed, in particular. in developing countries (Sinaga et al. 2021; Turan and Kara, 2018). In addition, the use of digital media for entrepreneurs can reduce costs and increase efficiency (Basri and Siam, 2017; Higón, 2011).

In the current era of modern society, new businesses including Micro, Small, and Medium Enterprises (MSMEs) are very important in helping to increase national economic growth. In Indonesia, one of the characteristics of domestic economic activity is that it is dominated by MSMEs, although the ratio of MSMEs to large companies varies in various economic sectors. Based on data from the Indonesian Ministry of Cooperatives and SMEs for the period 1997-2017, the number of MSMEs in Indonesia increases every year from 39,765 units (or about $99.8 \%$ of business units) in 1997 to more than 59 million business units (or 99.9\%) in 2017, except in 1998 when the Asian financial crisis hit Indonesia, the number of MSMEs fell by more than $7 \%$ (BPS, 2017). However, the increase in the number of new businesses and MSMEs in Indonesia is not followed by their contribution to the formation of gross domestic product (GDP). In terms of job creation, the role of MSMEs is always smaller than large companies (Tambunan, 2019), for example, of the total employment of $99 \%$, MSMEs only contributed $61.41 \%$ of GDP in 2017. Factors that cause this include capital, human resources, and access to technology that hinder the productivity of MSMEs is much lower than that of large businesses.

Due to limited resources, to expand market segmentation in the current digital economy era, new business actors tend to learn about the use of digital media strategies by observing various role models in digital media who display various content strategies related to business development (Park et al. 2017; Rozaq et al. 2020, 2021; Toutain et al. 2017). Previous literature has shown how an entrepreneur learns from various role models in a particular environment, for example from other people (Bosma et al. 2012; Lévesque et al. 2009), parents (Hamilton, 2011; Hoffmann et al. 2015), guest speakers (Fiet, 2001), co-workers (Kacperczyk, 2013; Zozimo et al. 2017). However, no previous research has discussed the acceptance of entrepreneurship from observations on digital media, given that success in learning by observing role models in digital media depends on the entrepreneur's ability to interpret, assess and apply the knowledge obtained from observations.

To examine the phenomenon of learning carried out by entrepreneurs through observations on digital media, this study used the social cognitive theory by Alber $(1977,2001)$. There are three forms of social learning in social cognitive theory, among others, through direct role models in the immediate environment such as parents or co-workers, through verbal role models such as guest speakers, and symbolic role models such as works displayed on digital media. Regarding the use of digital media strategies that are learned by entrepreneurs from observations on digital media, symbolic role models fit very well with this research. Furthermore, to analyze the acceptance of novice entrepreneurs related to the use of digital media strategies learned from the results of observing role models in digital media in this study, the reception theory was used by Stuart (1973), considering that the success of learning gained from observing role models in digital media depends on individual acceptance in assessing and applying knowledge from the results learned. 
Reception theory provides a reception analysis that focuses on the audience's interpretation of the message content displayed by the media (Bødker, 2016; Steiner, 2016). Interpretation is a person's active condition in the process of thinking and searching for meaning which makes this identical with the learning activities obtained from observing role models in digital media which are influenced by individual factors, the media environment, and the behavior of using digital media strategies studied (Bandura, 2012). In this study, acceptance analysis is used to analyze the use of digital media strategies that entrepreneurs learn from observations on digital media. The reception analysis used is an encoding-decoding model which describes the circular circulation in the process of reproducing media messages from the results of learning behavior in the media environment that is consumed daily. Digital media can adopt an interactive encoding-decoding model which is divided into three acceptance positions, including dominant, negotiated, and oppositional positions (Shaw, 2017).

In the current era of digital technology, the phenomenon of learning carried out by entrepreneurs from observing role models in various digital media is very interesting to study, given that the literature related to learning in entrepreneurship is still very limited to explain the complexity and development of frameworks for entrepreneurial learning (Cope, 2005, 2011; Pittaway and Thorpe, 2012; Wang and Chugh, 2014). Thus, this research is expected to add to the wealth of literature on entrepreneurship learning that continues to grow along with the convergence of media and consumer trends.

This study aims to examine the acceptance of novice entrepreneurs in studying the use of digital media strategies from the observations of role models in digital media. To examine the phenomenon of learning about the use of digital media strategies carried out by entrepreneurs from the results of observing role models, an in-depth approach was carried out using a qualitative approach with a case study method for entrepreneurs who had just started a business in the first three years from the categories of micro, small, and medium enterprises according to with research purposes.

\section{METHODS}

The research was conducted using the interpretivism paradigm with a qualitative approach. Then to get an overview of the research phenomenon, a descriptive case study method is used, which is generally intended to provide a description in the form of a narrative related to the problem being studied (Yin, 2018). The location of the research was carried out in the city of Surakarta, Indonesia specifically carried out in a business place that was carrying out activities related to the use of digital media strategies in business communication activities.

The sampling technique used is non-probability sampling, which is purposive. We determine the entrepreneurial criteria according to the research objectives, including, (1) new businesses that are starting a business in the first three years running that have the potential to be developed, (2) new businesses that have utilized digital media as a tool for their business media, (3) new businesses classified as MSMEs as stipulated by the Ministry of Cooperatives and SMEs, Indonesia in 2019, (4) active on one of the digital media accounts as business activities in business development efforts. While the sampling technique used is sampling the maximum variation determined from annual income, type of business, and the number of workers.

Sources of data in this study in the form of primary data and secondary data obtained from the results of interviews, observations, and documents. The sampling technique for primary data was carried out using indepth interviews with entrepreneurs who were selected as resource persons in October 2020 - March 2021. In addition, the direct observation method was carried out on digital media used by entrepreneurs related to activities using digital media. Furthermore, secondary data used is in the form of data on the potential of MSMEs from the Central Statistics Agency (BPS), data on novice entrepreneurs, and MSMEs in Surakarta City from the Surakarta City Cooperatives and MSMEs Service.

A validity test is done by triangulation to get accuracy and alternative explanation. Then after the data is collected, data analysis techniques are carried out which include examining data, selecting data, classifying data, abstracting data, formulating propositions, compiling codes, presenting data, and evaluating propositions towards final propositions (Miles et al. 
2014; Taylor et al. 2016; Yin, 2018). To explain the research phenomenon related to the acceptance of entrepreneurship in learning about the use of digital media strategies from observations role models, it is described in Figure 1.

\section{RESULTS}

By the problem and to meet the research objectives, in this study the profile of the informants is presented concerning the concepts and sampling techniques previously described. To see the details of informant's profile in this study according to the data that the researcher obtained in the field, it is presented in Table 1.

\section{Entrepreneurial Learning About Using Digital Media Strategies}

In accordance with the explanation in the previous literature that entrepreneurship learning from observing role models, especially in digital media is described in three main factors in the triadic reciprocal determinant scheme (Bandura, 1977, 2021) which influence each other between personal, behavioral, and environmental factors that influence each other. each other. The results of the research from interviews conducted with entrepreneurs in studying the use of digital media strategies are as follows:

First, in learning about strategies for information dissemination and sharing with customers, FJR and ALD revealed that they observed several other business accounts on Instagram when they appeared on the homepage and on stories, for example, they observed strategies when informing new products, discounts, ongoing promotions, as well as changes in operating hours.

Furthermore, in learning about promotion and mobilization, ADT, a medium-sized business actor, revealed that in carrying out promotions he observed other businesses on social media as a reference, for example, how other businesses were aggressively creating content containing product offerings at low prices with good quality, and Fast service in the buying process. In line with this, ALD revealed that he observed the promotion strategies of several other businesses on social media and then developed them according to what was needed. In accordance with the previous literature which explains that content strategies that focus on promotion are usually often used by novice entrepreneurs, especially those who offer products and services that directly target previous consumers (Lovejoy and Saxton, 2012; Men and Tsai, 2012).

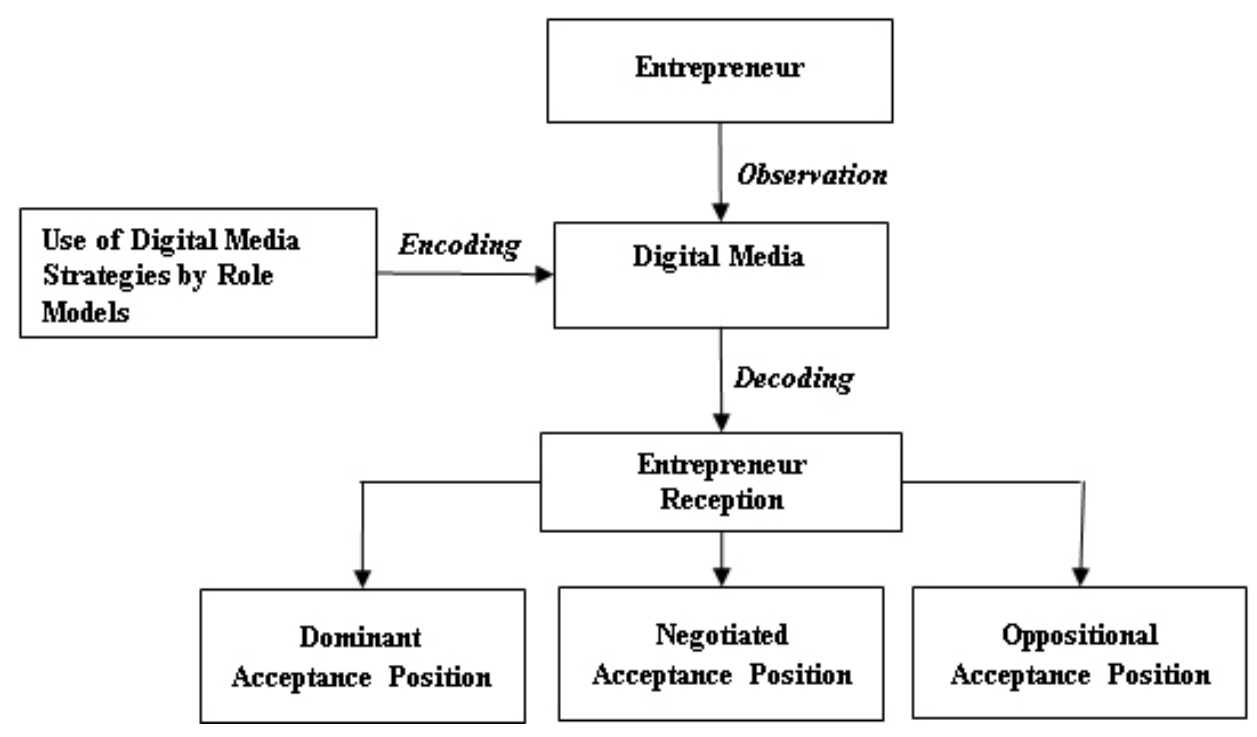

Figure 1. Research framework 
Tabel 1. Research Informants

\begin{tabular}{|c|c|c|c|c|c|}
\hline Informant & Type of business & $\begin{array}{c}\text { Business } \\
\text { Establishment }\end{array}$ & $\begin{array}{c}\text { Number of } \\
\text { Workers }\end{array}$ & Category & $\begin{array}{c}\text { Digital Media } \\
\text { Used }\end{array}$ \\
\hline $\mathrm{ADK}$ & $\begin{array}{l}\text { Women's Clothing and } \\
\text { Accessories }\end{array}$ & 3 years & 26 People & Medium Enterprises & $\begin{array}{l}\text { - Instagram } \\
\text { - Whatsapps } \\
\text { - Tiktok }\end{array}$ \\
\hline ADT & $\begin{array}{l}\text { Convection, and T-shirt } \\
\text { Making Services }\end{array}$ & 2 years & 20 People & Medium Enterprises & $\begin{array}{l}\text { - Instagram } \\
\text { - Facebook } \\
\text { - Whatsapps }\end{array}$ \\
\hline FJR & Culinary & 3 years & 20 People & Small Enterprises & $\begin{array}{l}\text { - Instagram } \\
\text { - Facebook } \\
\text { - Whatsapps }\end{array}$ \\
\hline ALD & Cafe and Restaurant & 6 months & 6 People & Small Enterprises & $\begin{array}{l}\text { - Instagram } \\
\text { - Facebook }\end{array}$ \\
\hline WHY & Packaged Beverages & 8 months & 3 People & Micro Enterprises & $\begin{array}{l}\text { - Instagram } \\
\text { - Whatapps }\end{array}$ \\
\hline $\mathrm{AN}$ & Culinary & 8 months & 2 People & Micro Enterprises & $\begin{array}{l}\text { - Instagram } \\
\text { - Facebook } \\
\text { - Whatsapp }\end{array}$ \\
\hline
\end{tabular}

Then, in learning about strategies for social listening, customer-service and dialogue, ADK, a medium business actor revealed that in learning about strategies for listening to customers, customer service and dialogue, the hijab influencers observed on social media became his inspiration, for example conducting two-way communication with customers on comment column or direct message when customers ask about the product they are looking for. Entrepreneurs think it is effective for maintaining relationships and solving customer problems. In line with this, FJR observed other similar businesses and implemented a relationship management strategy by optimizing search engine optimization (SEO) and replying to comments via Google Maps. The strategy of managing relationships for entrepreneurs is in accordance with what was shown by Men and Tsai (2012) that building and managing relationships are important for entrepreneurs in today's increasingly connected era.

Furthermore, in the process of learning about cobranding strategies, AN revealed that she learned from observing her business partners when collaborating to promote products, according to $\mathrm{AN}$, it was effective in reaching a wider range of customers. Meanwhile, ADT revealed that he was looking for references on the Website to learn how to expand his reach for promotions. The co-branding strategy used by novice entrepreneurs is in accordance with what was identified by (Chen et al. 2017) for wider exposure through collaboration.
Finally, in the process of learning about utilizing thirdparty endorsement from influencers, FJR revealed that he observed other businesses on social media while doing endorsements, then he followed up by promoting to several influencer accounts. Meanwhile, WHY saw other entrepreneurial trends and decided to endorse them when he first opened an outlet. Third-party influencer support is also an important digital communication strategy for entrepreneurs according to what is shown by (Chen et al. 2017) that the content posted by influencers can generate more engagement that has an impact on the business as a whole. The results of the study are described in the following Table 2.

The results show that entrepreneurs do not follow a certain model to be a role models. In digital media, entrepreneurs tend to see a lot of role models such as other business accounts, celebrities, content creators, and so on. In contrast to the results of previous research on entrepreneurship learning on the actual model in the direct environment of entrepreneurship which specifically describes the role model of entrepreneurship such as parents in the family environment (Hoffmann et al. 2015), resource persons (Fiet, 2001), colleagues and the environment. University (Kacperczyk, 2013). In the digital media environment, the model that is used as a role model by entrepreneurs using digital media strategies is not always in the form of an entrepreneurial figure but can be in the form of creative works such as visual and verbal content. This is in accordance with what was described by Bandura (Bandura, 1977) 
related to symbolic modeling in the mass media (Bandura, 2001) that the model can be in the form of real or fictional characters who display behavior in online media.

Meanwhile, the use of digital media strategies studied by entrepreneurs was mostly identified in previous research such as information dissemination and sharing, promotion and mobilization, social listening, customer service, and dialogue (Lovejoy and Saxton, 2012; Men and Tsai, 2012), and utilizing support thirdparty influencers (Chen et al. 2017). In addition, the digital media used to study the use of digital media strategies are mostly through observations on Instagram according to the digital media they use and they need which are currently used by all groups and are easy to learn. In addition, in studying the use of certain digital media strategies, entrepreneurs also observe several websites and youtube.

\section{Entrepreneurial Reception In Learning The Use of Digital Media Strategies}

It has been explained previously that success in learning by observing role models in digital media depends on the entrepreneur's ability to interpret, assess and apply the knowledge gained from observations. For this reason, this research uses reception analysis which provides an analysis of acceptance by the audience's interpretation of the content of messages displayed by the media
(Hall, 1973). In this study, acceptance analysis is used to analyze the use of digital media strategies learned by entrepreneurs from observations on digital media. reception analysis used is the encoding-decoding model. The results of the research from interviewing informants in the field are as follows:

\section{Dominant Position}

In this position, entrepreneurs interpret the same as what the role models show in digital media so that entrepreneurs no longer fully consider and accept what the role models have shown about the use of digital media strategies. The results of the study in the dominant position are as follows:

First, in the learning process of information dissemination and sharing strategies, entrepreneurs revealed that according to observations from other business actors how to always update information to customers, for example about promo programs being run, news about operating hours, this is very useful when practiced in business (ALD, April 4). In addition, AN and FJR argue that the strategy of observing models on digital media is very interesting to study and follow, such as information packaged through videos and photos about product reviews that combine several products in one content can inspire customers and give a business impression and product identity to always remembered.

Tabel 2. Entrepreneurial learning about using digital media strategies from observing role models

\begin{tabular}{clcc}
\hline Informant & Use of Learned Digital Media Strategies & Role Model & $\begin{array}{c}\text { Digital Media } \\
\text { Environment }\end{array}$ \\
\hline FJR & Information dissemination and sharing & Another venture & Instagram \\
ALD & & Another venture & Instagram \\
\hline ADT & Promotion and mobilization & Another venture & Instagram \\
ALD & & Another venture & Instagram \\
\hline ADK & Social listening, customer-service and dialogue & Celebgram & Instagram \\
FJR & & Another venture & Instagram \\
\hline AN & Co-branding & Business partner & Instagram \\
ADT & & Creator content & Website, Youtube \\
\hline FJR & Utilizing third-party endorsement from influencers & Another venture & Instagram \\
WHY & & Another venture & Instagram \\
\hline
\end{tabular}


Then in learning about promotion and mobilization, in this position, the entrepreneur believes that promotions carried out by several other businesses are very effective, such as offering low prices with good quality and fast service to please customers (ADK, January 11). In addition, ALD and WHY believe that conducting promotional programs on certain holidays is very effective as they have observed from several celebrity accounts.

In learning about strategies for listening to customers, customer service, and dialogue, in this position, the three entrepreneurs believe that what is shown by the model is very effective and can solve customer problems and complaints more quickly such as conducting two-way communication in the review column, direct messages, and whatsapps.

In learning about co-branding strategies, in this position, three entrepreneurs argue what they learned from observations on digital media such as collaboration with other larger digital media accounts to get bigger results. This can be done when holding certain programs such as watching movies together, live music, and so on.

Finally, in learning about the strategy of utilizing the support of third party influencers, in this position, the entrepreneur revealed that they observed several other businesses and then endorsed accounts such as @ kulinersolo (AN,4 March), @diskonsolo (ADT), @ agendasolo (ADK) who the results proved effective.

In a dominant position, entrepreneurs assume that adopting the observed use of digital media strategies will have an impact on business development so that entrepreneurs tend to imitate the use of similar digital media strategies according to what has been observed and learned.

\section{Negotiated Position}

This position is a combination position, on the one hand, entrepreneurs can accept what has been observed but they choose which ones are suitable or not in certain cases. They adjust the needs and objectives of their business strategy and develop what has been observed according to their prior knowledge. The results of the study in the negosiated position are as follows:

First, in learning about strategies for sharing information with customers. In this position, entrepreneurs reveal that informing customers is important but must pay attention to the details of the information in each content (WHY, February 18). In addition, other entrepreneurs argue that information needs to be made taking into account the identity of the business itself (ADT, April $4)$.

Second, in learning about promotion and mobilization strategies, in this position two entrepreneurs revealed that in learning promotion strategies observed from several social media accounts were not used as a benchmark, they only followed the style while the concept had to be adapted to their character as in the case of products.

Furthermore, in learning about strategies for listening to customers, customer service, and dialogue, in this position, ADT and WHY revealed that conducting twoway communication is important, but must be done by maximizing all use of social media, not only focusing on one social media.

Then, in learning about the co-branding strategy, in this position, ADT and ADK argue that in today's digital era, which is all connected, to get greater exposure, one must often collaborate not only within the scope of business partners but collaboration will be maximized to many.

Finally, in learning about strategies for leveraging influencer support, in this position, two entrepreneurs revealed that leveraging influencer support is very important, but it must be done selectively to choose influencers that match the target audience so that it can have an impact on the business as a whole.

In the negotiated position, the entrepreneur agrees with the observed strategy which is reinforced by the benefits generated by the observed model, but the entrepreneur also his knowledge and abilities so that in this position the entrepreneur prefers some use of digital media strategies which he thinks are effective, but in In certain cases, entrepreneurs make modifications by developing them according to their knowledge.

\section{Oppositional Position}

An oppositional position occurs when entrepreneurs accept the use of digital media strategies that are observed differently from what their role models display in digital media. This is because entrepreneurs 
have different views which are marked by a discrepancy with the observed use of digital media strategies. The results of the study in the oppositional position are as follows:

First, in the process of learning the strategy of disseminating and sharing information, in this position ADK revealed that to maximize the use of digital media as a strategy for sharing information with customers, it is necessary to divide according to the type of product and branch of business, Andrika sees that several other businesses that are used as role models only use one social media accounts, creating product-specific social media accounts can make it easier for customers to find products and to strengthen the identity of the product itself.

Furthermore, in learning about promotion and mobilization strategies, in this position, ADT revealed that carrying out promotional strategies on digital media several other businesses observed did so in ordinary ways. Aditya said that in the era of increasingly competitive technological developments, promotion and mobilization strategies must be carried out unconventionally. The product must be extraordinary and must determine the USP (unique selling proposition) that has a selling value.
In addition, in learning about the social listening to customers, customer service and dialogue, in this position ALD revealed that the strategy of managing customer relationships observed on digital media did not adjust to market segmentation.

Then in learning about the co-branding, in this position, WHY revealed that what was observed in the cobranding strategy carried out by other businesses only collaborated on larger business accounts and partners. According to him, collaboration can be done with all groups without exception to get wider exposure.

Finally, in learning about strategies for utilizing influencer support, WHY in this position revealed that in expanding exposure, it is not always necessary to take advantage of influencer support. He argues that targeted exposure is more important than simply expanding the content being distributed.

In the oppositional position regarding entrepreneurial learning about the use of digital media strategies, they rely more on their knowledge and ability to create digital media strategies according to their knowledge and abilities and tend to make new versions of strategies according to what is known. Entrepreneurial reception in learning the use of digital media strategies is described in detail in the following Table 3.

Tabel 3. Entrepreneurial reception in learning the use of digital media strategies

\begin{tabular}{|c|c|c|c|}
\hline \multirow{3}{*}{$\begin{array}{l}\text { Use of Learned Digital } \\
\text { Media Strategies }\end{array}$} & \multicolumn{3}{|c|}{ Entrepreneurial Receptions } \\
\hline & Dominant & Negotiated & Oppositional \\
\hline & Performs a similar Imitation & $\begin{array}{l}\text { Make modifications } \\
\text { (Development) }\end{array}$ & $\begin{array}{c}\text { Creating a new version } \\
\text { (Innovation) }\end{array}$ \\
\hline \multirow{3}{*}{$\begin{array}{l}\text { Strategy for disseminating } \\
\text { and sharing information with } \\
\text { customers }\end{array}$} & ALD & WHY & ADK \\
\hline & FJR & ADT & \\
\hline & $\mathrm{AN}$ & & \\
\hline \multirow{3}{*}{$\begin{array}{l}\text { Promotion and mobilization } \\
\text { strategies }\end{array}$} & ADK & $\mathrm{AN}$ & ADT \\
\hline & WHY & FJR & \\
\hline & ALD & & \\
\hline \multirow{3}{*}{$\begin{array}{l}\text { Listening to customers, } \\
\text { customer service and } \\
\text { dialogue }\end{array}$} & ADK & ADT & ALD \\
\hline & FJR & WHY & \\
\hline & $\mathrm{AN}$ & & \\
\hline \multirow[t]{3}{*}{ Co-branding strategy } & FJR & ADT & WHY \\
\hline & $\mathrm{AN}$ & ADK & \\
\hline & ALD & & \\
\hline \multirow{3}{*}{$\begin{array}{l}\text { Strategies to leverage } \\
\text { influencer support }\end{array}$} & $\mathrm{AN}$ & ALD & WHY \\
\hline & ADT & FJR & \\
\hline & ADK & & \\
\hline
\end{tabular}


The results show that most of the entrepreneurs accept the learning about the use of digital media strategies that are learned in each strategy, three entrepreneurs are in a dominant position, apart from being beginners, the strategies learned from role models are strategies that are believed to be effective to support their business development, while two entrepreneurs among them in each strategy are in a negotiating position and one entrepreneur is in a position of accepting opposition.

In the dominant position, thw entrepreneur is strengthened by a positive assessment that the strategy is effective to be practised in his business. The entrepreneur considers that the digital communication strategy has proven successful for the model itself. Some of the strategies that have been adopted by entrepreneurs have also proven successful. This is in accordance with what Bandura $(1986,2001)$ explained that reviving a behaviour in this case the use of digital media strategies depends on the consequences or rewards received by the observer when reenacting the behaviour. In other words, in the dominant acceptance position, entrepreneurs fully accept what is observed from the model and imitate similar strategies according to what has been learned.

In the position of acceptance of negotiations, cognitive factors such as previous knowledge that entrepreneurs have about the use of digital media strategies strengthen entrepreneurial self-efficacy which influences entrepreneurs to match back with what is observed, then develop digital media strategies from what has been learned. In other words, in the position of acceptance of the negotiation, the entrepreneur accepts some of the strategies that have been observed from the model in digital media, but in other cases, the $n$ entrepreneur also has self-efficacy in the knowledge and abilities possessed so that in this position, the entrepreneur considers what is observed from the model. develop according to their knowledge of digital media strategies.

In the position of acceptance of the opposition, previous knowledge about digital media strategies that they already have forms entrepreneurial self-efficacy in digital mediastrategies that are learned so that entrepreneurs believe that with knowledge of digital strategies they already have, they will be able to create more effective communication strategies for their businesses. In other words, in the process of learning digital media strategies in a position of acceptance of opposition, entrepreneurs have self-efficacy in their knowledge and abilities so that entrepreneurs rely more on their knowledge and abilities and decide to make digital media strategies according to their knowledge and abilities to get strategies new version.

\section{Managerial Implication}

The use of digital media strategies for new businesses and MSMEs is flexible and continues to evolve in line with technological developments and consumer trends. So that this research is expected to be able to contribute to the relevant agencies or institutions to understand the characteristics of new businesses and SMEs in conducting trainings held on the use of digital media. Furthermore, this research is expected to add to the wealth of literature on entrepreneurship learning, especially regarding the approaches and methods used, considering that no previous research has discussed in depth about how entrepreneurs learn from observing role models in digital media. Finally, this research is expected to add to the wealth of literature on the complexities of entrepreneurship learning, especially related to entrepreneurial reception in studying the use of digital media strategies for new businesses and MSMEs.

\section{CONCLUSIONS AND RECOMMENDATIONS}

\section{Conclusions}

Entrepreneurial reception in learning the use of digital media strategies shows that three entrepreneurs are in a dominant position in each use of digital media strategies learned. In this position, apart from being in a new business, the observed use of digital media strategies is easy to learn and commonly used for new businesses. Meanwhile, two entrepreneurs are in an oppositional position in each strategy. In this position, entrepreneurs tend to have more knowledge to develop according to the use of digital media strategies they need. In addition, one entrepreneur is in an oppositional position for each use of the digital media strategy learned, in an oppositional position the entrepreneur has longer experience in carrying out digital media strategies in line with the length of time the business was founded and has better resources. 


\section{Recommendations}

This research relies on a case study of entrepreneurs in the city of Surakarta. The empirical generalizations of this study are limited and are not the aim of this study. Therefore it must be generalizable. In accordance with the results of the study, it allows further research to test: The relationship between entrepreneurial relationships and their role models on digital media. Testing previous knowledge or relating to entrepreneurial relationships such as education, experiences that determine selfefficacy in interpreting digital media strategy tasks that are known on digital media.

\section{REFERENCE}

Bandura A. 1977. Social Learning Theory. Englewood Cliffs. New Jersey: Prentice-Hall, Inc.

Bandura A. 1986. Social Foundations of Thought and Action: A Social Cognitive Theory. Englewood Cliffs, NJ: Prentice-Hall.

Bandura A. 2001. Social cognitive theory of mass communication. Media Psychology 3(3):265-99. https://doi.org/10.1207/ S1532785XMEP0303_03

Bandura, A. 2012. Social Cognitif Theory. Handbook of Theories of Social Psychology. Ed. ke-1. Lange PAMV, Kruglanski AW, Higgins, editor. London: Sage Publications Ltd.

Basri WS, Mohammed RA. S. 2017. Maximizing the Social media potential for small businesses and startups: A conceptual study. International Journal of Economic Perspectives 11(2):24145.

Bosma N, Jolanda H, Veronique S, Mirjam VP, Ingrid VD. 2012. Entrepreneurship and role models. Journal of Economic Psychology 33(2):410-24. https://doi.org/10.1016/j.joep.2011.03.004

Bresciani S, Martin JE. 2010. Brand new ventures? insights on start-ups' branding practices. Journal of Product and Brand Management 19(5):35666. https://doi.org/10.1108/10610421011068595

Chen ZF, Yi GJ, Linjuan RM. 2017. Strategic use of social media for stakeholder engagement in startup companies in china. International Journal of Strategic Communication 11(3):1-24. https:// doi.org/10.1080/1553118X.2017.1298114

Fiet JO. 2001. The theoretical side of entrepreneurship theory. Journal of Business Venturing 16(1):1-24. https://doi.org/10.1016/S0883-9026(99)00041-5
Hall S. 1973. Encoding, Decoding. In: During $S$ (Ed.) The Cultural Studies Reader. London: Routledge.

Higón HA. 2011. The Impact of ict on innovation activities: Evidence for UK SMEs. International Small Business Journa 30(6):684-99. https:// doi.org/10.1177/0266242610374484

Hoffmann A, Martin J, Nikolaj MM. 2015. Running in the family: parental role models in entrepreneurship. Small Business Economics 44(1):79-104. https://doi.org/10.1007/s11187014-9586-0

Horst SO, Rita JT, Francisco JPL. 2019. Entrepreneurial identity development through digital media. Journal of Media Business Studies 1-26.

Kacperczyk AJ. 2013. Social influence and entrepreneurship: The effect of university peers on entrepreneurial entry. Organization Science 24(3):664-83. https://doi.org/10.1287/ orsc. 1120.0773

Lovejoy K, Gregory D. 2012. Information, community, and action: How nonprofit organizations use social media. Journal of Computer-Mediated Communication 17(3):337-53. https://doi. org/10.1111/j.1083-6101.2012.01576.x

Men LR, Wan HST. 2012. How companies cultivate relationships with publics on social network sites: Evidence from China and the United States. Public Relations Review 38:723-30. https://doi. org/10.1016/j.pubrev.2011.10.006

Miles MB, Michael H, Johnny S. 2014. Qualitative Data Analysis: A Methods Sourcebook. Ed. ke-3. Arizona State University: SAGE Publications, Inc.

Park JY, Chang SS, Il Im. 2017. Does social media use influence entrepreneurial opportunity? A review of its moderating role. Sustainability (Switzerland) 9(9):1-16. https://doi.org/10.3390/ su9091593

Rini MN, Muhammad RS. 2019. Strategi media sosial untuk pengembangan umkm. Jurnal Terapan Teknologi Informasi 2(2):159-70. https://doi. org/10.21460/jutei.2018.22.125

Rozaq M, Sri H, Yulius S. 2020. Digital Modeling through Observation of Content on Social Media in the Learning Process of Novice Entrepreneurial Communication Strategies." In 6th International Conference on Social and Political Sciences (ICOSAPS 2020) Digital. Vol. 510. hlm 153-161.

Rozaq M, Sri H, Yulius S. 2021. How novice 
entrepreneurs learn about digital marketing communication strategies?. Jurnal ASPIKOM 6(2):345-59. https://doi.org/10.24329/aspikom. v6i2.936

Shaw A. 2017. Encoding and decoding affordances: Stuart hall and interactive media technologies. Media, Culture and Society 39(4):592-602. https://doi.org/10.1177/0163443717692741

Sinaga J, Elisa A, Alim SS. 2021. The effect of supply chain management practices and information and communication technology on competitive advantage and firm performance (Case study: Smes of processed food in Jakarta). Indonesian Journal of Business and Entrepreneurship 7(1):91-101. https://doi.org/10.17358/ ijbe.7.1.91

Taiminen HM, Heikki K. 2015. The usage of digital marketing channels in smes. Journal of Small Business and Enterprise Development 22(4):633-51.
Tambunan T. 2019. Recent evidence of the development of micro, small and medium enterprises in Indonesia. Journal of Global Entrepreneurship Research 9(1):1-15. https://doi.org/10.1186/ s40497-018-0140-4

Turan M, Ali K. 2018. Online social media usage behavior of entrepreneurs in an emerging market: Reasons, expected benefits and intentions. Journal of Research in Marketing and Entrepreneurship 20(2):1-19. https://doi. org/10.1108/JRME-09-2016-0034

Wang CL, Harveen C. 2014. Entrepreneurial learning: Past research and future challenges. International Journal of Management Reviews 16(1):24-61. https://doi.org/10.1111/ijmr.12007

Yin RK. 2018. Case Study Research and Applications: Design and Method. Ed. ke-6. Los Angeles.

Zozimo R, Sarah J, Eleanor H. 2017. Entrepreneurial learning from observing role models. Entrepreneurship and Regional Development $1-23$. 